\title{
ANALISIS PRODUKTIFITAS GAS HIDROGEN DAN GAS OKSIGEN PADA ELEKTROLISIS LARUTAN KOH
}

\author{
Arbie Marwan Putra ${ }^{1}$ \\ e-mail: pujangga_muslim@yahoo.com
}

\begin{abstract}
Abstrak : Teknologi mengubah air menjadi sumber energi sudah mulai banyak ditemukan. Para ilmuan mempunyai metode masing-masing tentang pengubahan air menjadi energi. Salah satunya menggunakan metode elektrolisis, yaitu mengubah ikatan air $\left(\mathrm{H}_{2} \mathrm{O}\right)$ menjadi senyawa penyusunnya $\mathrm{H}_{2}$ yang mudah terbakar dan $\mathrm{O}_{2}$ berfungsi membantu proses pembakaran. Hal yang mempengaruhi terjadinya elektrolisis adalah konsenterasi larutan dan arus listrik. Dalam penelitian ini larutan yang digunakan adalah larutan $\mathrm{KOH}$ sedangakan arus listrik berasal dari power supply DC sebagai sumber tegangan kemudian dianalisis menggunakan metode analisis regresi. Hasil penelitian diperoleh bahwa produktifitas $\mathrm{H}_{2}$ pada saat arus 4A persamaan regresi adalah $\hat{\mathrm{Y}}=22,82$ $+4,607 \mathrm{X}$ dan pada saat konsenterasi $4 \%$ persamaan regresi adalah $\hat{\mathrm{Y}}=-3,049+10,91 \mathrm{X}$. Sedangkan produktifitas $\mathrm{O}_{2}$ pada saat konsentersi larutan $4 \%$ persamaan regresi yang dihasilkan adalah $\hat{\mathrm{Y}}=-2,032+7,276 \mathrm{X}$ dan pada saat arus $4 \mathrm{~A}$ adalah $\hat{\mathrm{Y}}=15,21+$ $3,071 \mathrm{X}$.
\end{abstract}

Kata Kunci: Air $\left(\mathrm{H}_{2} \mathrm{O}\right)$, Gas Hidrogen, Gas Oksigen, Elektrolisis

\section{PENDAHULUAN}

Teknologi mengubah air menjadi bahan bakar, akhir-akhir ini sudah dilakukan penelitian oleh beberapa ilmuan. Untuk menghasilkan sesuatu yang ideal tentang pengubahan air tersebut, masing-masing para ilmuan menggunakan metode yang berbeda-beda. Sejatinya teori yang mengkaji tentang mengubah air menjadi bahan bakar memang sudah ada sejak puluhan tahun silam. Elektrolisis merupakan metode yang ditemukan oleh para ilmuan, yakni untuk memutuskan ikatan pada dua senyawa yang terdapat pada air.

$\mathrm{KOH}$ merupakan senyawa basa, jika dilarutkan ke dalam air maka akan membentuk larutan $\mathrm{KOH}$. $\mathrm{KOH}$ tersebut akan menjadi katalisator yang berfungsi untuk mempermudah pemutusan ikatan gas hidrogen dan oksigen dalam air. Semakin besar konsenterasi larutan $\mathrm{KOH}$ ketika dielektrolisis, diduga semakin besar pula peluang untuk menghasilkaan gas hidrogen dan oksigen dalam jumlah yang banyak. Begitu pula pengaruh arus yang diberikan oleh sumber tegangan. Semakin besar arus yang diberikan semakin banyak gelembung-gelembung yang muncul dari permukaan katoda. Gelembung-gelembung tersebut diduga merupakan proses pemutusan ikatan antara $\mathrm{H}_{2}$ dan $\mathrm{O}_{2}$ di dalam senyawa air sehingga $\mathrm{H}_{2}$ dan $\mathrm{O}_{2}$ semakin banyak.

\footnotetext{
${ }^{1}$ Fisika UIN Maulana Malik Ibrahim Malang
} 
Untuk itu, perlu diadakan penelitian lebih lanjut tentang bagaimana pengaruh konsenterasi $\mathrm{KOH}$ dan arus listrik yang terjadi ketika proses elektrolisis dalam menghasilkan gas hidrogen dan oksigen yang nantinya berguna sebagai rujukan sumber bahan bakar alternatif masa depan. Sehingga judul penelitian ini "Analisis Produktifitas Gas Hidrogen dan Oksigen Pada Elektrolisis Larutan KOH'.

\section{KAJIAN TEORI}

\section{A. Metode Pemisahan Kimia}

Metode pemisahan merupakan aspek penting dalam bidang kimia karena kebanyakan materi yang terdapat dialam berupa campuran. Untuk memperoleh materi murni dari suatu campuran, kita harus melakukan pemisahan. Berbagai teknik pemisahan dapat diterapkan untuk memisahkan campuran. Perusahaan air minum memperoleh air jernih dari air sungai dengan cara penyaringan pasir dan arang (Hendayana,2006:1).

Air murni untuk keperluan laboratorium atau farmasi diperoleh melalui teknik pemisahan destilasi. Untuk memisahkan minyak bumi menjadi komponenkomponennya seperti LPG, bensin, minyak tanah dilakukan dengan metode destilasi bertingkat. Logam aluminium dipisahkan dari bauksit melalui teknik pemisahan elektrolisis (Hendayana,2006:1).

Begitu juga dengan gas hidrogen dan oksigen dalam air dipisahkan dengan cara elektrolisis. Melalui teknik pemisahan, ternyata menghasilkan materi yang lebih penting dan lebih mahal harganya (Hendayana,2006:1).

\section{B. Elektrolosis}

Alat elektrolisis terdiri atas sel elektrolisis yang berisi elektrolit (larutan atau leburan). Pada elektrolisis biasa kita selalu menggunakan elektroda yang sama dimasukkan dalam larutan yang bersangkutan. Pada elektrolisis yang menghasilkan $\mathrm{H}_{2}$ dan $\mathrm{O}_{2}$ ternyata timbulnya kedua gas ini baru mulai setelah $\mathrm{E}$ lebih besar dari 1,7 Volt (Achmad,1992:92-93).

Ada 2 prinsip yang khas dari elektrolisis yaitu kaitan antara beda potensial yang digunakan dan arus yang mengalir melalui sel elektrolisis. Serta discas yang selektif diantara ion-ion pada permukaan elektroda. Pada potensial-urai tiba-tiba bertambah, pada saat elektrolisis mulai berlangsung pada elektron. Menghasilkan hidrogen dan oksigen (Achmad,1992:92-93).

Anoda: $2 \mathrm{H}_{2} \mathrm{O} \rightarrow 4 \mathrm{H}^{+}+\mathrm{O}_{2(\mathrm{~g})}+4 \mathrm{e}$

Katoda: $2 \mathrm{H}^{+}+2 \mathrm{e} \rightarrow \mathrm{H}_{2}(\mathrm{~g})$

Agar terjadi elektrolisis diperlukan potensial minimum karena: 
1. Adanya beda potensial antara elektroda menyebabkan ion-ion dalam sistem bergerak ke elektroda. Hidrogen dan oksigen yang mula-mula terbentuk menutupi permukaan elektroda dan reaksi sebaliknya yang terjadi. Perhatikan reaksi setengah sel,

$4 \mathrm{H}^{+}+\mathrm{O}_{2}+4 \mathrm{e} \rightarrow 2 \mathrm{H}_{2} \mathrm{O} \quad \mathrm{E}^{0}=-1,23 \mathrm{~V}$

$2 \mathrm{H}^{+}+2 \mathrm{e} \rightarrow \mathrm{H}_{2} \quad \mathrm{E}^{0}=0.00 \mathrm{~V}$

Beda potensial harus sekurang-kurangnya mengimbangi DGL balik yang disebabkan oleh penyerapan hasil elektrolisis pada permukaan elektroda. Potensialurai teoritis untuk asam sulfat adalah $1,23 \mathrm{~V}$.

2. Diperlukan potensial tambahan untuk discas ion pada elektrolisis yang disebut potensial-lebih (over potensial. Potensial lebih merupakan ukuran energi pengaktifan bagi reaksi elektroda. Reaksi pada elektroda yang menghasilkan gas memerlukan potensial lebih yang besar.

\begin{tabular}{|c|c|c|}
\hline Gas yang timbul & Permukaan elektroda & Potensial lebih (volt) \\
\hline Hidrogen & Platina & 0,03 \\
\hline Oksigen & Platina & 0,44 \\
\hline Hidrogen & Perak & 0,15 \\
\hline Oksigen & Perak & 0,45 \\
\hline Hidrogen & Raksa & 0,78 \\
\hline Oksigen & Grafit & 0,37 \\
\hline klor & Platiana & 0,70 \\
\hline
\end{tabular}

Tabel 1. Potensial Lebih Beberapa Zat

\section{Hidrogen}

Hidrogen adalah unsur yang terdapat dialam yang kelimpahan terbesar, tetapi hanya sedikit tertinggal di bumi. Dari analisis spectrum sinar yang dipancarkan oleh bintang, disimpulkan bahwa bintang terutama terdiri dari hidrogen. Hidrogen sangat reaktif sehingga di bumi hidrogen terdapat sebagai senyawa air mengandung hidrogen sebanyak $11,1 \%$ berat $(11,1 \%)$, hidrokarbon misalnya gas alam $25 \%$, minyak bumi $14 \%$ dan karbohidrat, misalnya patih $6 \%$. Beberapa sifat fisika Hidrogen sebagai berikut:

Lambang

Nomor Atom

Konfigurasi electron

Massa atom relative
$\mathrm{H}$

1

$1 s^{1}$

1,008 
Energy ionisasi/kJ mol ${ }^{-1} \quad 1310$

Kerapatan $/ \mathrm{g} \mathrm{cm}^{-3} \quad 0,00009$

Titik didih/K 20

Temperature kritik 33

Jari-jari atom/nm $\quad 0,037$

Potensi elektroda standard/V $\quad 0$

\section{Cara Menghasilkan Hidrogen:}

1. Mengalirkan uap air melalui karbon panas

$\mathrm{C}_{(\mathrm{s})}+\mathrm{H}_{2} \mathrm{O} \rightarrow \mathrm{CO}_{(\mathrm{g})}+\mathrm{H}_{2}(\mathrm{~g})$

$\mathrm{H}_{2}$ yang dihasilkan dengan cara ini tidak murni sebab sukar memisahkan CO. campuran $\mathrm{H}_{2}$ dan $\mathrm{CO}$ disebut gas air. Gas air termasuk bahan bakar penting dan mempunyai kalor pembakaran besar.

2. Mengalirkan uap air melalui besi panas

$3 \mathrm{Fe}_{(\mathrm{s})}+4 \mathrm{H}_{2} \mathrm{O} \rightarrow \mathrm{Fe}_{3} \mathrm{O}_{4}+4 \mathrm{H}_{2(\mathrm{~g})}$

3. Pada kilang minyak bumi, hidrogen merupakan hasil samping dari cracking hidrokarbon. Gas hidrokarbon dialirkan melalui katalis panas dan terurai menjadi hidrogen dan hidrokarbon lain. Hidrokarbon yang lebih ringan seperti metana (metana dapat juga berasal dari gas alam), dipanaskan dengan suhu $750^{\circ} \mathrm{C}$ dan tekana $10 \mathrm{~atm}$,

$\mathrm{CH}_{4(\mathrm{~g})}+\mathrm{H}_{2} \mathrm{O}_{(\mathrm{g})} \rightarrow \mathrm{CO}_{(\mathrm{g})}+3 \mathrm{H}_{2(\mathrm{~g})}$

4. Hidrogen yang sangat murni $(99,9 \%)$, tetapi mahal, diperoleh dengan cara elektrolisis air.

$2 \mathrm{H}_{2} \mathrm{O} \rightarrow 2 \mathrm{H}_{2}(\mathrm{~g})+\mathrm{O}_{2(\mathrm{~g})}$

(Jumlah hidrogen yang cukup banyak diperoleh juga dari hasil samping industri klor-alkali, dimana diperoleh $\mathrm{Cl}_{2}$ dan $\mathrm{NaOH}$ dari elektrolisis larutan $\mathrm{NaCl}$ ).

5. Di laboratorium hidrogen murni diperoleh dari reduksi ion hidrogen dengan logam seng (pada prinsipnya dengan logam yang potensial elektodanya negatif) $\mathrm{Zn}_{(\mathrm{s})}+2 \mathrm{H}^{+} \rightarrow \mathrm{Zn}^{2+}+\mathrm{H}_{2(\mathrm{~g})}$

Selain dari pada itu dari reaksi logam aluminium dengan basa

$2 \mathrm{Al}_{(\mathrm{s})}+2 \mathrm{OH}^{-}+6 \mathrm{H}_{2} \mathrm{O} \rightarrow 2 \mathrm{Al}(\mathrm{OH})_{4}{ }^{-}+3 \mathrm{H}_{2(\mathrm{~g})}$

Atau $\mathrm{CaH}_{2}$ dengan air

$\mathrm{CaH}_{2}(\mathrm{~s})+2 \mathrm{H}_{2} \mathrm{O} \rightarrow \mathrm{Ca}^{2+}+2 \mathrm{OH}^{-}+2 \mathrm{H}_{2(\mathrm{~g})}$ 


\section{E. Ikatan Hidrogen}

Dalam beberapa senyawa hidrogen, atom hidrogen menjembatani dua atom yang keelektronegatifannya besar, membentuk ikatan yang disebut ikatan hidrogen. Ikatan hidrogen terjadi antara atom yang kecil dan sangat elektronegatif seperti fluor, oksigen, dan nitrogen. Senyawa $\mathrm{HF}, \mathrm{H}_{2} \mathrm{O}$, dan $\mathrm{NH}_{3}$ mempunyai ikatan hidrogen baik dalam keadaan padat maupun cairan. Karena ikatan ini dalam keadaan gas pun terjadi polimer HF (Achmad.1992:12-23).

Oleh karena pada proses pelelehan dan penguapan sejumlah ikatan hidrogen perlu diputuskan, senyawa ini mempunyai titik didih yang tinggi. Oleh karena itu urutan titik didih sebagai berikut:

$$
\begin{aligned}
& \mathrm{H}_{2} \mathrm{O}>\mathrm{H}_{2} \mathrm{~S}<\mathrm{H}_{2} \mathrm{Se}<\mathrm{H}_{2} \mathrm{Te} \\
& \mathrm{HF}>\mathrm{HCl}<\mathrm{HBr}<\mathrm{HI} \\
& \mathrm{NH}_{3}>\mathrm{PH}_{3}<\mathrm{AsH}_{3}<\mathrm{SbH}_{3} \\
& \mathrm{CH}_{4}<\mathrm{SiH}_{4}<\mathrm{GeH}_{4}<\mathrm{SnH}_{4} \\
& \mathrm{Ne}<\mathrm{Ar}<\mathrm{Kr}<\mathrm{Xe}
\end{aligned}
$$

Meskipun ikatan hidrogen relatif lemah $(\sim 20 \mathrm{~kJ})$ dibandingkan dengan ikatan kimia lainnya $(\sim 20 \mathrm{~kJ})$, ikatan hidrogen ini sangat penting dalam sistem kehidupan misalnya dalam protein yang terdapat pada iktan hidrogen dalam gugus $-\mathrm{CO}$ dan gugus -NH (Achmad.1992:12-23).

\section{F. Hidrogen Sebagai Bahan Bakar}

Pembakaran hidrogen dapat menghasilkan kalor sebanyak $286 \mathrm{~kJ}$ per mol hidrogen. Pada tabel dibawah ini dapat dibandingkan kalor yang dihasilkan oleh hidrogen dengan kalor yang dihasilkan oleh bahan bakar lain,

\begin{tabular}{|c|c|c|c|}
\hline \multirow{2}{*}{ Bahan Bakar } & \multicolumn{3}{|c|}{ Kalor yang dihasilakn (kJ) } \\
\cline { 2 - 4 } & Per gram & Per mol & Per liter \\
\hline Gas hidrogen & 143 & 286 & 12 \\
\hline Hidrogen cair & 142 & 285 & 9970 \\
\hline Gas metan & 55 & 882 & 36 \\
\hline LPG & 50 & 2220 & 25600 \\
\hline Oktana cair & 48 & 5512 & 3400 \\
\hline
\end{tabular}

Tabel 2. Perbandingan Kalor 
Hidrogen dapat digunakan sebagai bahan bakar sebab:

1. Dapat terbakar dalam oksigen membentuk air dan menghasilkan energy.

2. Bersama oksigen dapat digunakan dalam sel bahan bakar menghasilkan energi listrik.

Keuntungan jika hidrogen digunakan sebagai bahan bakar yaitu:

1. Suatu cuplikan hidrogen jika dibakar akan menghasilkan energi sebanyak kira-kira tiga kali energi yang dihasilkan bensin dengan berat yang sama.

2. Dalam mesin kendaraan bermotor hidrogen akan terbakar lebih efisien jika dibandingkan dengan bahan bakar lain.

3. Pembakaran hidrogen kurang menghasilkan polusi. Polutan yang terjadi hanya oksida nitrogen yang terjadi jika suhu pembakaran sangat tinggi.

4. Mesin yang menggunakan hidrogen mudah diubah agar dapat menggunakan hidrogen sebagai bahan bakar.

Alasan utama mengapa hidrogen masih belum digunakan secara besar-besaran sebagai sumber energi yaitu:

1. Produksi hidrogen masih cukup mahal

2. Kesukaran dalam menyimpan

\section{G. Penyimpanan Hidrogen}

Hidrogen dapat disimpan dengan cara berikut:

1. Hidrogen dicairkan dan disimpan pada suhu $-253^{\circ} \mathrm{C}$. dalam hal ini memerlukan tangki khusus dan mahal. Hidrogen cair perlahan-lahan menguap dan dapat meledak. Energi untuk mencairkan hidrogen kira-kira $40 \%$ energi yang dihasilkan pada pembakaran.

2. Dapat disimpan dalam tangki berukuran tinggi kira-kira 30 kali dibandingkan tangki berisi bensin yang menghasilkan energi yang sama.

3. Dapat disimpan dalam aliasi logam. Hidrogen dapat menempati rongga diantara atom aliasi logam dan membentuk hidrida (hidrida interstisi). Hidrida logam ini aman untuk pengisian hidrogen karena tidak meledak jika gas dibakar.

Untuk menyimpan sejumlah hidrogen yang dapat menghasilkan energi sebanyak energi yang dihasilkan dalam tangki bensin rata-rata diperlukan $1000 \mathrm{~kg}$ aliasi besi titanium.

\section{H. Penggunaan Hidrogen}

1. Sintesis amonia.

2. Pembuatan asam nitrat (oksidasi amonia menghasilkan NO; amonia diperoleh dari hasil haber). 
3. Pembuatan margarin. Minyak yang merupakan ester tidak jenuh diubah menjadi senyawa yang jenuh menggunakan katalis nikel Ramey.

4. Pembuatan bahan bakar "petroleum". Dengan menggunakan katalis, serbuk batu bara diubah menjadi minyak hdrokarbon (petroleum hidrocarbon), kemudian disuling menjadi bensin, minyak pelumas, dan sebagainya. $1 \mathrm{~kg}$ batu bara dapat menghasilkan $1 \mathrm{dm}^{3}$ bensin).

5. Sintesa metanol.

6. Hidrogen adalah gas yang paling ringan. Sering digunakan untuk balon meteorologi.

7. Digunakan sebagai cairan krigonik untuk menghasilkan suhu rendah.

8. Reaksi dengan $\mathrm{O}_{2}$ menghasilkan energi besar. Pembakar (obor) oksihidrogen dapat menghasilkan suhu $2500^{\circ} \mathrm{C}$. Oleh karena kalor pembakaran yang besar $120 \mathrm{~kJ} / \mathrm{g}$ cairan hidrogen digunakan sebagai bahan bakar roket.

9. Dalam jangka panjang untuk mengatasi problema energi, hidrogen dapat menarik perhatian, karena bahan baku air berlimpah-limpah.

\section{METODOLOGI}

\section{A. Bentuk dan Sampel Penelitian}

Bentuk penelitian ini adalah pembuatan dan analisis alat untuk mengetahui produktifitas $\mathrm{H}_{2}$ dan $\mathrm{O}_{2}$ ketika proses elektrolisis. Sampel yang digunakan adalah larutan $\mathrm{KOH}$.

\section{B. Alat dan Bahan}

Agar penelitian dapat dilaksanakan dengan baik, maka dalam hal ini dibutuhkan beberapa alat dan bahan yang dapat mendukung jalannya percobaan. Adapun alat dan bahan yang digunakan adalah Tabung Elektrolizer terbuat dari bahan mika (plastik), Elektroda 10 buah terbuat dari bahan stainless, kabel, power supply DC, Larutan $\mathrm{KOH}$.

\section{Rancangan Alat}

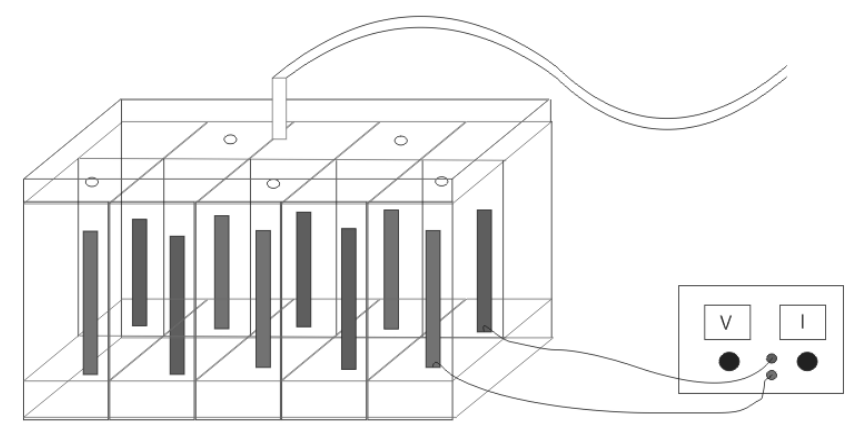

Gambar 1. Rancangan Alat 


\section{Langkah Kerja Penelitian}

1. Elektroda positif dan negatif dirangkai ke dalam tabung elektrolizer yang membentuk 5 sel dan dianalogikan seperti tabung $\mathrm{U}$, dengan ketentuan elektroda negatif dan positif disusun saling bersilangan

2. $\mathrm{KOH}$ direaksikan dengan air sehingga terbentuk larutan $\mathrm{KOH}$. Besarnya konsenterasi larutan $\mathrm{KOH}$ kemudian diukur dengan menggunakan persamaan:

$\%$ konsenterasi larutan $=\operatorname{massa}(\mathrm{g}) \mathrm{KOH} \times 100 /$ volume $(\mathrm{ml})$ air

Massa $\mathrm{KOH}$ yang digunakan adalah $40 \mathrm{~g}$ kemudian dilarutkan di dalam air 750 $\mathrm{ml}, 875 \mathrm{ml}, 1000 \mathrm{ml}, 1125 \mathrm{ml}, 1250 \mathrm{ml}$ sehingga konsenterasi larutan $\mathrm{KOH}$ yang terbentuk $5,33 \%, 4,57 \%, 4 \%, 3,55 \%, 3,2 \%$.

3. Larutan $\mathrm{KOH}$ yang kemudian diisikan ke dalam tabung elektrolizer.

4. Sesama elektroda positif (merah) dan elektroda negatif (biru) dihubungkan menggunakan kabel, kemudian diteruskan menuju power supply DC.

5. Agar muncul gelembung-gelembung pada permukaan lempeng elektroda sebaiknya menggunakan arus diatas 3 A. Jika kurang dari 3 A sulit dijumpai gelembung-gelembung pada katoda. Pada penelitian ini, arus pada power supply DC diatur 4A, 4,5A, 5A, 5,5A, dan 6A pada setiap konsenterasi larutan untuk menghasilkan gas hidrogen dan oksigen sehingga muncul gelembunggelembung pada permukaan katoda.

6. Lubang keluaran tabung elektrolizer dihubungkan dengan selang pengukur gas yang sebelumnya telah diisi air, sehingga apabila timbul gas maka gas tersebut akan mendorong air keluar dari selang.

7. Pergerekan air pada selang pengukur gas diukur dari titik $0 \mathrm{~cm}$ sampai $30 \mathrm{~cm}$, sehingga dihasilkan waktu tempuh atau kecepatan debit gas yang kemudian dikonversikan dalam satuan volume. Persamaan volume pada selang pengukur gas adalah:

Volume $=\pi r^{2} \cdot p$

1 liter $\quad=1 \mathrm{dm}^{3}$

$1000 \mathrm{ml}=1000 \mathrm{~cm}^{3}$

Dengan $\pi=3,14$, jari-jari $(\mathrm{r})=2,5 \mathrm{~cm}$ dan panjang selang $(\mathrm{p})=30 \mathrm{~cm}$, sehingga dapat diketahui kapasitas volume pada selang pengukur gas adalah $588,75 \mathrm{~cm}^{3}$.

8. Volume gas hasil elektrolisis yang telah diketahui kemudian diuraikan sehingga didapatkan volume gas hidrogen dan gas oksigen dengan persamaan kimia:

$2 \mathrm{KOH}+2 \mathrm{H}_{2} \mathrm{O} \rightarrow \mathrm{K}_{2}+3 \mathrm{H}_{2}+2 \mathrm{O}_{2}$

Artinya dalam $100 \mathrm{ml}$ gas hasil elektrolisis terdapat $60 \mathrm{ml}$ gas hidrogen dan 40 $\mathrm{ml}$ gas oksigen.

\section{HASIL DAN PEMBAHASAN}

Data yang dihasilkan dari pengujian alat adalah dapat diuraikan dalam sebuah tabel sebagai berikut: 


\begin{tabular}{|c|c|c|c|c|c|}
\hline $\begin{array}{l}\text { Konsenterasi } \\
\text { Larutan } \mathrm{KOH}\end{array}$ & $\begin{array}{l}\text { Arus DC } \\
\text { (Ampere) }\end{array}$ & $\begin{array}{c}\text { Waktu } \\
\text { Tempuh Gas } \\
/ 30 \mathrm{~cm} \\
\text { (detik) }\end{array}$ & $\begin{array}{c}\text { Debit } \\
\text { Volume } \\
\text { gas/detik } \\
(\mathrm{ml} / \mathrm{s})\end{array}$ & $\begin{array}{c}\text { Debit } \\
\text { Volume } \\
\mathrm{H}_{2}(\mathrm{ml} / \mathrm{s})\end{array}$ & $\begin{array}{c}\text { Debit } \\
\text { Volume } \\
\mathrm{O}_{2}(\mathrm{ml} / \mathrm{s})\end{array}$ \\
\hline \multirow[t]{5}{*}{$5,33 \%$} & 4 & 7,48 & 78,71 & 47,226 & 31,484 \\
\hline & 4,5 & 6,76 & 87,09 & 52,254 & 34,836 \\
\hline & 5 & 5,96 & 98,78 & 59,268 & 39,512 \\
\hline & 5,5 & 5.24 & 112,36 & 67,416 & 44,944 \\
\hline & 6 & 4,64 & 126,88 & 76,128 & 50,752 \\
\hline \multirow[t]{5}{*}{$4,57 \%$} & 4 & 8,03 & 73,32 & 43,992 & 29,328 \\
\hline & 4,5 & 7,20 & 81,77 & 49,062 & 32,708 \\
\hline & 5 & 6,48 & 90,86 & 54,516 & 36,344 \\
\hline & 5,5 & 5,78 & 101,86 & 61,116 & 40,744 \\
\hline & 6 & 4,97 & 118,46 & 71,076 & 47,384 \\
\hline \multirow[t]{5}{*}{$4 \%$} & 4 & 8,53 & 69,02 & 41,412 & 27,608 \\
\hline & 4,5 & 7,73 & 76,16 & 45,696 & 30,464 \\
\hline & 5 & 6,95 & 84,71 & 50,826 & 33,884 \\
\hline & 5,5 & 6,28 & 93,75 & 56,25 & 37,5 \\
\hline & 6 & 5,57 & 105,7 & 63,42 & 42,28 \\
\hline \multirow[t]{5}{*}{$3,55 \%$} & 4 & 8,98 & 65,56 & 39,336 & 26,224 \\
\hline & 4,5 & 8,22 & 71,62 & 42,972 & 28,648 \\
\hline & 5 & 7,52 & 78,29 & 46,974 & 31,316 \\
\hline & 5,5 & 6,71 & 87,74 & 52,644 & 35,096 \\
\hline & 6 & 6,03 & 97,64 & 58,584 & 39,056 \\
\hline \multirow[t]{5}{*}{$3,2 \%$} & 4 & 9,47 & 62,17 & 37,302 & 24,868 \\
\hline & 4,5 & 8,76 & 67,21 & 40,326 & 26,884 \\
\hline & 5 & 7,94 & 74,15 & 44,49 & 29,66 \\
\hline & 5,5 & 7,26 & 81,09 & 48,654 & 32,436 \\
\hline & 6 & 6,55 & 89,88 & 53,928 & 35,952 \\
\hline
\end{tabular}

Tabel 3. Data Hasil Percobaan

Larutan $\mathrm{KOH}$ merupakan senyawa larutan kimia dengan melarutkan $\mathrm{KOH}$ ke dalam air. Reaksi kimia yang terjadi pada larutan tersebut adalah sebagai berikut:

$$
2 \mathrm{KOH}+2 \mathrm{H}_{2} \mathrm{O} \rightarrow \mathrm{K}_{2}+3 \mathrm{H}_{2}+2 \mathrm{O}_{2}
$$

Reaksi kimia tersebut menunjukkan jika 2 bagian $\mathrm{KOH}$ dilarutkan ke dalam 2 bagian air dan kemudian di elektrolisis, maka akan terjadi penguraian senyawa yang terjadi, yaitu $\mathrm{K}_{2}$ yang berupa padatan akan tetap bertahan di dalam larutan, sedangkan 3 bagian $\mathrm{H}_{2}$ dan 2 bagian $\mathrm{O}_{2}$ akan keluar menguap ke udara. Gas hidrogen inilah yang kemudian ditampung dan dijadikan bahan bakar alternatif masa depan.

Gas hidrogen adalah gas yang mudah dibakar, jika dipakai untuk pembakaran sepeda motor, oktan yang dihasilkan lebih tinggi dari pada oktan yang dihasilkan oleh pertamax dan bensin. Sedangkan gas oksigen adalah gas yang membantu pembakaran. Api akan hidup jika berada di dalam ruangan yang memilki oksigen. Demikian peristiwa sebaliknya bahwa api tidak akan bisa hidup jika berada diruangan hampa. 
Banyak sekali pemanfaatan gas hidrogen untuk masa depan, selain digunakan sebagai bahan bakar kendaraan juga dapat dijadikan sumber pembangkit listrik. Hal ini dapat terjadi karena gas hidrogen mudah meledak, hasil ledakan hidrogen inilah yang kemudian dapat dijadikan penggerak turbin sehingga dapat memutar generator dan kemudian menjadi energi listrik. Dan masih banyak lagi manfaat-manfaat lainnya dari gas hidrogen.

Proses elektrolisis terjadi karena adanya kutub katoda dan anoda yang saling berhadapan. Jika melihat susunan katoda dan anoda pada tabung elektrolizer dalam penelitian ini maka dapat dilihat peluang terjadinya elektrolisis adalah sebanyak 13 buah kutub yang saling berhadapan. Hal ini tidak terjadi jika seandainya kutub yang saling berhadapan disusun secara paralel. Jika disusun secara paralel maka peluang terjadi elektrolisis hanya 5 buah kutub yang saling berhadapan. Semakin banyak kutub yang saling berhadapan anatara katoda dan anoda maka semakin banyak gas yang dihasilkan.

Konsenterasi larutan merupakan nilai kepekatan kandungan zat atau senyawa yang dilarutkan ke dalam air. Semakin banyak zat atau senyawa yang dilarutkan ke dalam air maka akan semakin pekat larutan tersebut. Semakin pekat larutan KOH maka akan membuat besarnya hambatan listrik pada larutan akan semakin kecil dan akan mendekati nol. Besarnya arus sangat mempengaruhi proses terjadinya elektrolisis. Arus yang pada umumnya kurang dari 1 Ampere sangat sulit dijumpai gelembunggelumbung yang muncul pada permukaan elektroda. Semakin besar arus yang diberikan maka semakin cepat munculnya gelembung-gelembung di permukaan elektroda. Ini berarti produktifitas gas hidrogen dan oksigen semakin cepat dan mudah.

Dengan menghubungkan antara konsenterasi larutan dan arus pada proses elektrolisis, maka perbandingan produktifitas gas hidrogen dan gas oksigen dapat dijelaskan melelui diagram tabel berikut:

\begin{tabular}{|c|c|c|c|c|c|c|}
\hline \multirow{2}{*}{\multicolumn{2}{|c|}{ Produktifitas $\mathrm{H}_{2}$}} & \multicolumn{5}{|c|}{ Konsenterasi Larutan $\mathrm{KOH}$} \\
\hline & & $3,20 \%$ & $3,55 \%$ & $4,00 \%$ & $4,57 \%$ & $5,33 \%$ \\
\hline \multirow{5}{*}{$\sum_{2}^{\infty}$} & $4 \mathrm{~A}$ & 37,302 & 39,336 & 41,412 & 43,992 & 47,226 \\
\hline & $4,5 \mathrm{~A}$ & 40,326 & 42,972 & 45,696 & 49,062 & 52,254 \\
\hline & $5 \mathrm{~A}$ & 44,49 & 46,974 & 50,826 & 54,516 & 59,268 \\
\hline & $5,5 \mathrm{~A}$ & 48,654 & 52,644 & 56,25 & 61,116 & 67,416 \\
\hline & $6 \mathrm{~A}$ & 53,928 & 58,584 & 63,42 & 71,076 & 76,128 \\
\hline \multirow{2}{*}{\multicolumn{2}{|c|}{ Produktifitas $\mathrm{O}_{2}$}} & \multicolumn{5}{|c|}{ Konsenterasi Larutan $\mathrm{KOH} \mathrm{( \% )}$} \\
\hline & & $3,20 \%$ & $3,55 \%$ & $4,00 \%$ & $4,57 \%$ & $5,33 \%$ \\
\hline \multirow{5}{*}{ 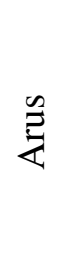 } & $4 \mathrm{~A}$ & 24,868 & 26,224 & 27,608 & 29,328 & 31,484 \\
\hline & $4,5 \mathrm{~A}$ & 26,884 & 28,648 & 30,464 & 32,708 & 34,836 \\
\hline & $5 \mathrm{~A}$ & 29,66 & 31,316 & 33,884 & 36,344 & 39,512 \\
\hline & $5,5 \mathrm{~A}$ & 32,436 & 35,096 & 37,5 & 40,744 & 44,944 \\
\hline & $6 \mathrm{~A}$ & 35,952 & 39,056 & 42,28 & 47,384 & 50,752 \\
\hline
\end{tabular}

Tabel 4. Perbandingan Produktivitas Hidrogen dan Oksigen 
Dari diagram tabel produktifitas $\mathrm{H}_{2}$ dan $\mathrm{O}_{2}$ diatas, menunjukkan produktifitas $\mathrm{H}_{2}$ dan $\mathrm{O}_{2}$ terdapat pada titik maksimum produksi dan titik minimum produksi. Untuk titik produktifitas minimum terjadi pada saat konsenterasi larutan $\mathrm{KOH} \mathrm{3,2 \%} \mathrm{dan} \mathrm{arus} 4 \mathrm{~A}$, sedangkan produktifitas $\mathrm{H}_{2}$ dan $\mathrm{O}_{2}$ pada titik produktifitas maksimum terjadi pada saat konsenterasi larutan 5,33\% dan arus $6 \mathrm{~A}$.

Regresi yang digunakan adalah regresi $\mathrm{Y}$ atas $\mathrm{X}$, yaitu $\mathrm{X}$ yang mewakili sumbu $\mathrm{X}$ merupakan variabel bebas dan $\mathrm{Y}$ yang mewakili sumbu y merupakan variabel tak bebas. Untuk mendapatkan peresamaan regresi linier sederhana, sebaiknya menggunakan program menu grafik yang terdapat pada fasilitas Microsoft Excel. Ini bertujuan untuk mempermudah mendapatkan persamaan regresi yang tepat dan akurat jika dibandingkan dengan menggunakan perhitungan manual. Oleh karena itu didapatkan persamaan regresi melalui grafik sebagai berikut:

1. Persamaan regresi produktifitas $\mathrm{H}_{2}$ terhadap konsentersi larutan

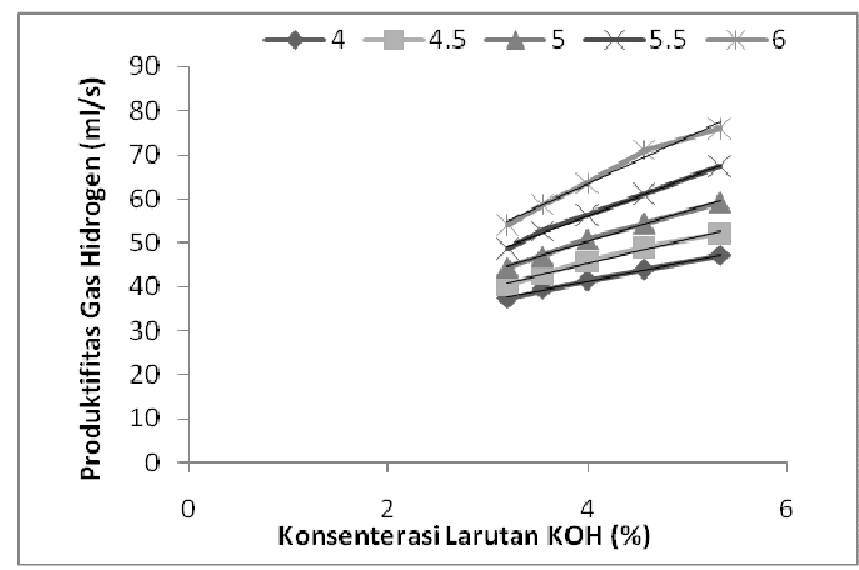

\begin{tabular}{|c|c|c|}
\hline Arus & Persamaan Regresi & $\mathrm{R}^{2}$ \\
\hline 4 A & $\hat{\mathrm{Y}}=22,82+4,607 \mathrm{X}$ & 0,997 \\
\hline 4,5 A & $\hat{\mathrm{Y}}=23+5,584 \mathrm{X}$ & 0,988 \\
\hline 5 A & $\hat{\mathrm{Y}}=22,42+6,971 \mathrm{X}$ & 0,996 \\
\hline 5,5 A & $\hat{\mathrm{Y}}=21,45+8,659 \mathrm{X}$ & 0,997 \\
\hline 6 A & $\hat{\mathrm{Y}}=20,81+10,60 \mathrm{X}$ & 0,983 \\
\hline
\end{tabular}

Dari persamaan regresi yang didapat di atas, untuk melakukan uji prediksi produktifitas, ambil salah satu persamaan, misal $\hat{Y}=22,82+4,607 X$. Jika konsnterasi larutan 10\% misalnya. Dengan jalan memasukkan variabel tersebut kedalam persamaan di atas, diprediksikan produktifitas gas hidrogen yang dihasilkan adalah sebesar 68,89 $\mathrm{ml} / \mathrm{s}$. 
2. Persamaan regresi produktifitas $\mathrm{H}_{2}$ terhadap pengaruh arus listrik

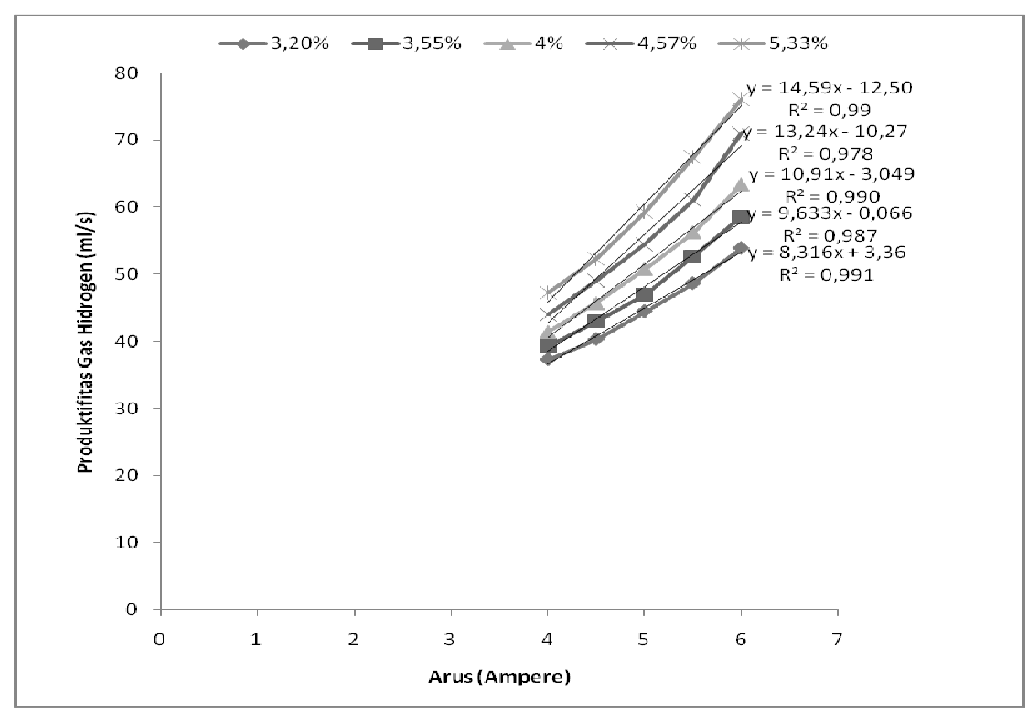

\begin{tabular}{|c|c|c|}
\hline Konsenterasi & Persamaan Regresi & $\mathrm{R}^{2}$ \\
\hline $3,20 \%$ & $\hat{\mathrm{Y}}=3,36+8,316 \mathrm{X}$ & 0,991 \\
\hline $3,55 \%$ & $\hat{\mathrm{Y}}=-0,066+9,633 \mathrm{X}$ & 0,987 \\
\hline $4 \%$ & $\hat{\mathrm{Y}}=-3,049+10,91 \mathrm{X}$ & 0,990 \\
\hline $4,57 \%$ & $\hat{\mathrm{Y}}=-10,27+13,24 \mathrm{X}$ & 0,978 \\
\hline $5,33 \%$ & $\hat{\mathrm{Y}}=-12,50+14,59 \mathrm{X}$ & 0,99 \\
\hline
\end{tabular}

Dari persamaan regresi yang didapat di atas, untuk melakukan uji prediksi produktifitas, ambil salah satu persamaan, misal $\hat{Y}=-12,50+14,59 X$. Jika arus listrik 3A misalnya. Dengan jalan memasukkan variabel tersebut kedalam persamaan di atas, diprediksikan produktifitas gas hidrogen yang dihasilkan adalah sebesar 31,27 ml/s.

3. Persamaan regresi produktifitas $\mathrm{O}_{2}$ terhadap pengaruh konsentersi larutan

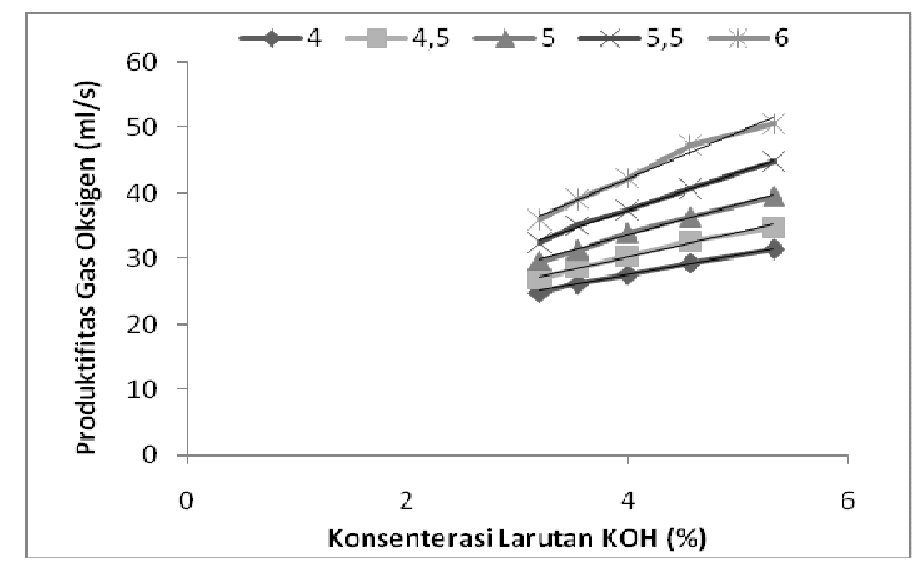




\begin{tabular}{|c|c|c|}
\hline Arus & Persamaan Regresi & $\mathrm{R}^{2}$ \\
\hline 4 A & $\hat{\mathrm{Y}}=15,21+3,071 \mathrm{X}$ & 0,997 \\
\hline 4,5 A & $\hat{\mathrm{Y}}=15,33+3,722 \mathrm{X}$ & 0,988 \\
\hline 5 A & $\hat{\mathrm{Y}}=14,94+4,677 \mathrm{X}$ & 0,996 \\
\hline $5,5 \mathrm{~A}$ & $\hat{\mathrm{Y}}=14,30+5,773 \mathrm{X}$ & 0,997 \\
\hline $6 \mathrm{~A}$ & $\hat{\mathrm{Y}}=13,87+7,071 \mathrm{X}$ & 0,983 \\
\hline
\end{tabular}

Dari persamaan regresi yang didapat di atas, untuk melakukan uji prediksi produktifitas, ambil salah satu persamaan, misal $\hat{Y}=14,94+4,677 X$. Jika konsnterasi larutan $15 \%$ misalnya. Dengan jalan memasukkan variabel tersebut kedalam persamaan di atas, diprediksikan produktifitas gas oksigen yang dihasilkan adalah sebesar 85,095 $\mathrm{ml} / \mathrm{s}$.

4. Persamaan regresi produktifitas $\mathrm{O}_{2}$ terhadap pengaruh arus listrik

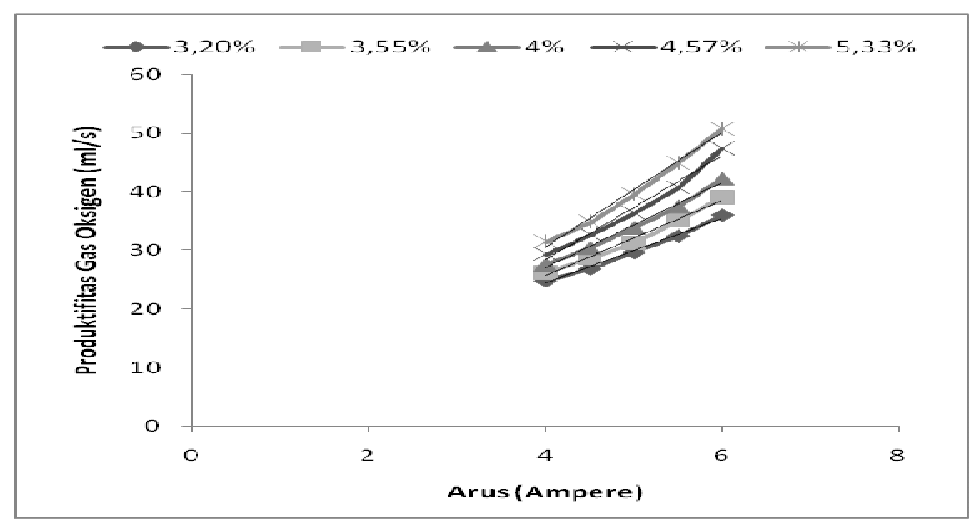

\begin{tabular}{|c|c|c|}
\hline Konsenterasi & Persamaan Regresi & $\mathrm{R}^{2}$ \\
\hline $3,20 \%$ & $\hat{\mathrm{Y}}=2,24+5,544 \mathrm{X}$ & 0,991 \\
\hline $3,55 \%$ & $\hat{\mathrm{Y}}=-0,044+6,422 \mathrm{X}$ & 0,987 \\
\hline $4 \%$ & $\hat{\mathrm{Y}}=-2,032+7,276 \mathrm{X}$ & 0,990 \\
\hline $4,57 \%$ & $\hat{\mathrm{Y}}=-6,846+8,829 \mathrm{X}$ & 0,978 \\
\hline $5,33 \%$ & $\hat{\mathrm{Y}}=-8,338+9,728 \mathrm{X}$ & 0,99 \\
\hline
\end{tabular}

Dari persamaan regresi yang didapat di atas, untuk melakukan uji prediksi produktifitas, ambil salah satu persamaan, misal $\hat{Y}=-6,846+8,829 X$. Jika arus listrik 20A misalnya. Dengan jalan memasukkan variabel tersebut ke dalam persamaan di atas, diprediksikan produktifitas gas hidrogen yang dihasilkan adalah sebesar 169,734 ml/s.

\section{KESIMPULAN}

1. Konsenterasi larutan merupakan nilai kepekatan kandungan zat atau senyawa yang dilarutkan ke dalam air. Semakin banyak zat atau senyawa yang dilarutkan ke dalam air maka akan semakin pekat larutan tersebut. Semakin pekat larutan $\mathrm{KOH}$ maka akan membuat besarnya hambatan listrik pada larutan akan semakin kecil dan akan 
mendekati nol. Gejala ini berarti menunjukkan semakin besar konsenterasi larutan ketika proses elektrolisis maka semakin besar pula volume gas yang dihasilkan. Sehingga untuk menghasilkan $\mathrm{H}_{2}$ dan $\mathrm{O}_{2}$ dalam jumlah yang banyak hal yang harus dilakukan adalah dengan memperbesar konsenterasi larutan. Begitu pula dengan arus. Besarnya arus sangat mempengaruhi proses terjadinya elektrolisis. Arus yang pada umumnya kurang dari 1 A sangat sulit dijumpai gelembung-gelembung yang muncul pada permukaan elektroda. Semakin besar arus yang diberikan maka semakin cepat munculnya gelembung-gelembung di permukaan elektroda. Gejala ini berarti menunjukkan semakin besar arus yang diberikan ketika proses elektrolisis maka semakin besar pula volume gas yang dihasilkan. Sehingga untuk menghasilkan $\mathrm{H}_{2}$ dan $\mathrm{O}_{2}$ dalam jumlah yang banyak hal yang harus dilakukan adalah dengan memperbesar arus.

2. Regresi yang digunakan adalah regresi $\mathrm{Y}$ atas $\mathrm{X}$, yaitu $\mathrm{X}$ yang mewakili sumbu $\mathrm{X}$ merupakan variabel bebas dan Y yang mewakili sumbu y merupakan variabel tak bebas. Regresi yang didapat selanjutnya digunakan untuk ramalan apabila harga variabel bebas diketahui.

\section{DAFTAR PUSTAKA}

Achmad, H. 1992. Elektro Kimia dan Kinetika Kimia. Citra Aditya Bakti: Bandung. Achmad, H. 1992. Kimia Unsur dan Radio Kimia. Citra Aditya Bakti: Bandung.

Achmad, H. 1992. Wujud Zat dan Kesetimbangan Kimia. Citra Aditya Bakti: Bandung.

Emoto, M. 2006. The True Power of Water. MQ Publishing: Bandung.

Hendayana, S. 2006. Kimia Pemisahan Metode Kromatografi dan Elektroforesis Modern. Remaja Rosdakarya Offset: Bandung.

Jun, W. 2008. Mengubah Air Menjadi Bensin. Pustaka Radja: Yogyakarta.

Sembiring. 1995. Analisis Regresi. ITB: Bandung.

Sudjana. 1996. Metoda Statistika. Tarsito: Bandung.

Sukardjo. 1989. Kimia Fisika. Rineka Cipta: Jakarta 